RESEARCH ARTICLE

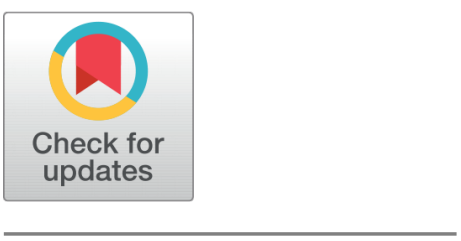

open ACCESS

Received: 04.05.2021

Accepted: 18.10 .2021

Published: 28.10 .2021

Citation: Gavino ZC, Gunnawa VV, Cammagay JR, Mariani MJP (2021) Sensory Evaluation of Blended Taro (Colocasia Esculenta) and Sweet Potato (Ipomoea Batatas) Polvoron. Indian Journal of Science and Technology 14(35): 2784-2788. https ://doi.org/10.17485/IJST/v14i35.766

* Corresponding author.

mpmariani@ksu.edu.ph

Funding: None

Competing Interests: None

Copyright: ( 2021 Gavino et al. This is an open access article distributed under the terms of the Creative Commons Attribution License, which permits unrestricted use, distribution, and reproduction in any medium, provided the original author and source are credited.

Published By Indian Society for Education and Environment (iSee)

ISSN

Print: 0974-6846

Electronic: 0974-5645

\section{Sensory Evaluation of Blended Taro (Colocasia Esculenta) and Sweet Potato (Ipomoea Batatas) Polvoron}

\author{
Zorayda C Gavino ${ }^{1}$, Vida V Gunnawa ${ }^{1}$, Jeanny R Cammagay ${ }^{1}$, \\ Mathew Jun P Mariani ${ }^{1 *}$ \\ 1 Kalinga State University, Philippines
}

\section{Abstract}

Objectives: This sensory evaluation study is aimed for an acceptable formulation of Taro and Sweet Potato for Polvoron. Polvoron is one of the pastry foods that can be quickly done by local entrepreneurs, unemployed youths, and Filipino households as a source of income. Methods: Three treatments were presented with different Taro and Sweet Potato flour mixed in ratio and kept other ingredients constant. The thirty (30) panelists evaluated the product's palatability, texture, flavor, moldability, and overall acceptability. The Data analysis tools used were Chi-square $(x 2)$ to test the significant differences among the treatments and frequency to quantify the sensory evaluation assessment. Findings: Taro and Sweet Potato flour ratio of mixture influence the product quality. Treatment 1 (control) received a higher frequency than the other treatments in terms of general acceptability. When it comes to relevance, texture and moldability were discovered to have substantial changes among treatments. In contrast, the computed F-value of 8.332 is less than the important value of 15.51 at a 0.5 level of significance, indicating that the treatments are not significantly different in terms of overall acceptability among the three (3) combinations. Novelty: This study highlighted the suitable blending of taro and sweet potato when creating a healthy and locally available polvoron.

Keywords: Blended Taro and Sweet Potato; Sensory; Acceptability; Polvoron; Flour

\section{Introduction}

Food poverty affects almost one billion people worldwide. According to the United States Agency for International Development (USAID), food protection requires having constant physical and economic access to enough food to fulfill nutritional requirements for a prosperous and stable life. Simply put, families can afford and access sufficiently healthy food. A family is food safe because none of its members are hungry or fearful of going hungry. Food deficiency is often associated with hunger in both the United States and developed countries. Shifts in the global economy, such as increases in global food and energy prices, can impact food production globally, with low-income countries 
bearing the brunt of the consequences ${ }^{(1)}$.

Tropical root and tuber crops' (TRCs) contribution to energy and calorie supply varies by zone. The annual global production of these crops, which is approximately 836 million tons, demonstrates their relative significance. Asia is the most prolific producer, followed by Africa, Europe, and North America. TRC demand in developing countries is expected to rise by 58 percent (from 232 million tons to 635 million tons) between 2003 and 2020. With cassava rising by 44 percent, potato increasing by 29 percent, sweet potato increasing by 27 percent, and yam increasing by 27 percent. Food demand will outpace feed demand for cassava and potatoes, while the situation will be reversed ${ }^{(2)}$.

With a world's population of 7.3 billion people, food supply and health continue to be issued. The global undernourishment rate ranges between 6 and $20 \%$. Undernourishment is widespread in the South Pacific Islands, ranging from 3 to 14 percent. Food shortages exist, and $\$ 12,669$ million in goods are imported. Furthermore, obesity and diabetes are rising due to globalization and shifts in eating habits, necessitating the scramble for healthier foods. Taro, cassava, sweet potato, and yam root crops are the primary sources of 40-50 percent of energy and nutrients. These are high in electricity, fiber, calcium, iron, and vitamins. Root crops can provide up to $24 \%$ of the energy needed and $100 \%$ of Vitamin C. Root crops are also functional foods, and nutraceutical ingredients that protect against chronic diseases aid in maintaining good health ${ }^{(3)}$.

Starchy roots and tuber crops are essential components of the human diet. Several roots and tubers belong to several species and make extensive biodiversity even within the exact geographical location. Starchy roots and tubers have been a component of human food habits since the dawn of humanity, and they provide diversity to the western diet while also providing several nutritional benefits and health implications such as antiobesity, antioxidative, hypoglycemic, hypocholesterolemic, antimicrobial, and immunomodulatory roles, to name a few ${ }^{(4)}$. Effectually, all root and tuber crops contribute 5.4 percent of overall human energy requirements from $61.1 \mathrm{~kg}$ tubers per head per year. Tuber crops alone contribute 3.9 percent of this total, resulting in an average of $28.6 \mathrm{~kg} / \mathrm{capita} /$ year $(76 \mathrm{kcal} / \mathrm{capita} /$ day). It is expected that by 2030 , this contribution will have more than doubled to $8 \%{ }^{(5)}$.

However, many consumers find the bitter taste of vegetables or other sensory features undesirable, threatening dietary guidelines to increase vegetable intake. Food is a multisensory experience, with diverse relationships between senses and human variations in sensory perception ${ }^{(6)}$. Effective combinations of usable ingredients and production methods provide the desired sensory qualities needed to attract non-vegetarian consumers. Sensory science is a broader research area that measures and interprets consumer reactions to product properties that are not limited to consumer likes. Sensory properties of food derivatives, such as color, flavor, texture, and mouthfeel, may be modified by including functional ingredients and the preference of processing methods ${ }^{(7)}$.

Food scientists must work with agriculturists, nutrition experts, society organizations, and policymakers to develop an integrated plan for sustainably feeding an expanding population. The current emphasis on food security is primarily on agricultural production and nutrition, sanitation, and well-being. The required conversion of raw materials into nutritious, usable, and culturally appropriate food items is vital in the food supply chain between production and consumption. Without a greater focus on the importance of food production in ensuring a healthy food supply, we are unlikely to solve the mounting difficulties in providing sustainable diets for all ${ }^{(8)}$.

With this, the researchers were able to develop different mixtures of taro and sweet potato root crops flour to put value improvement, leading to an accepted polvoron product. Polvoron is one of the pastry foods that can be quickly done by local entrepreneurs, unemployed youths, and Filipino households as a source of income. It may also improve the welfare of the farmers because they are allowed to increase their income by venturing into the massive production of these two crops. Moreover, local food products may be more advantageous to consumers than being constantly dependent on imported food products.

\section{Materials and Methods}

The descriptive correlational analysis approach was used to achieve the study's objectives. Descriptive analysis entails collecting evidence explaining activities, organizing, tabulating, depicting, and describing the data gathered. The purpose of this study was to shed light on an agreed formulated blending of taro and Sweet Potato into polvoron and to evaluate acceptability through sensory assessment.

The products were presented for evaluation to the 30 panelists. There were fifteen males and fifteen females from the age bracket of 15 to 40 chosen to evaluate. The palatability, texture, flavor, moldability, and overall acceptability of the treatments were assessed through organoleptic sensory evaluation. Each panelist was given three coded samples of polvoron and a score sheet in which they have checked the corresponding space of their assessment. 


\subsection{Procedure in making Taro and Sweet Potato flour}

Collect Taro and Sweet Potato, wash and clean it thoroughly to remove unnecessary particles, and start peeling. Prepare the Taro and Sweet Potato for paring and washing. After which, cut it into thin slices and dry it under the sun or use a dryer. When the products are dried, start grinding it. Sieve the ground taro and sweet potato powder to produce a better quality of the flour.

\subsection{Procedure in making blended Taro and Sweet Potato Polvoron}

Strain the taro and potato flour. After which, toast Taro and Sweet Potato flour until light brown. Mix the toasted Taro and Sweet Potato flour powder, milk, and white sugar. Start melting the butter and mix gradually with the mixture of toasted flour. If the mixture is ready for molding, use a polvoron molder, then wrap it with celluloid or Japanese paper.

\subsection{Statistical analysis}

Frequencies and Chi-square (x2) were used to interpret the data, which were gathered meaningfully. The frequency was used to quantify the sensory evaluation of the panelists on the different attributes per treatment through the 5 Point Likert Scale shown in Table 1. At the same time, the proportion and ingredients of blended Taro and Sweet Potato Polvoron per treatment are shown in Table 2.

Table 1. Likert Scale Sensory Evaluation

\begin{tabular}{|c|c|c|c|c|c|c|}
\hline \multirow{2}{*}{ Value } & \multirow{2}{*}{ Limits } & \multicolumn{5}{|l|}{ Description } \\
\hline & & Palatabilty & Texture & Moldability & Flavor & Overall Acceptability \\
\hline 5 & 5.00 & Extremely Palatable & Extremely Smooth & $\begin{array}{l}\text { Extremely } \\
\text { Molded }\end{array}$ & $\begin{array}{l}\text { Extremely Fla- } \\
\text { vored }\end{array}$ & Extremely Accepted \\
\hline 4 & $4.00-4.99$ & Very Much Palatable & $\begin{array}{l}\text { Very } \\
\text { Smooth }\end{array}$ & $\begin{array}{l}\text { Very } \\
\text { Molded }\end{array}$ & $\begin{array}{l}\text { Very } \\
\text { Flavored }\end{array}$ & Very Much Accepted \\
\hline 3 & $3.00-3.99$ & Moderately Palatable & $\begin{array}{l}\text { Moderately } \\
\text { Smooth }\end{array}$ & $\begin{array}{l}\text { Moderately } \\
\text { Molded }\end{array}$ & $\begin{array}{l}\text { Moderately } \\
\text { Flavored }\end{array}$ & Moderately Accepted \\
\hline 2 & $2.00-2.99$ & Slightly Palatable & Slightly Smooth & Slightly Molded & Slightly Flavored & Slightly Accepted \\
\hline 1 & $1.00-1.99$ & Not Palatable & Not Smooth & Not Molded & Not Flavored & Not Accepted \\
\hline
\end{tabular}

Table 2. Proportion and ingredients of blended Taro and Sweet Potato polvoron

\begin{tabular}{llll}
\hline & Treatments & & \\
\cline { 2 - 4 } & 1 (Control) & 2 & 3 \\
\hline Taro Flour & $1 \frac{1}{2}$ cups & 2 cups & 1 cup \\
Sweet Potato Flour & $1 \frac{1}{2}$ cups & 1 cup & 2 cups \\
Skim Milk & $1 \frac{1}{2}$ cups & $1 \frac{1}{2}$ cups & $1 \frac{1}{2}$ cups \\
Sugar & $1 \frac{1}{2}$ cups & $1 \frac{1}{2}$ cups & $1 \frac{1}{2}$ cups \\
Margarine & $1 \frac{1}{2}$ cups & $1 \frac{1}{2}$ cups & $1 \frac{1}{2}$ cups \\
\hline
\end{tabular}

Chi-square (x2) statistic was used to test the significant differences among the treatments. The measure for independence measures two variables in a contingency table to determine whether they are associated. In a broader context, it examines why the distributions of categorical variables vary from one another.

Formula:

$$
\mathrm{X}^{2} \mathrm{C}=\frac{(\mathrm{Oi}-\mathrm{Ei})^{2}}{\mathrm{Ei}}
$$

Where:

$\mathrm{C}=$ degrees of freedom

$\mathrm{O}=$ observed value $(\mathrm{s})$

$\mathrm{E}=$ expected value $(\mathrm{s})$

$$
\operatorname{Ei}(\mathrm{r}, \mathrm{c})=\frac{\mathrm{n}(\mathrm{r}) \times \mathrm{c}(\mathrm{r})}{\mathrm{n}}
$$




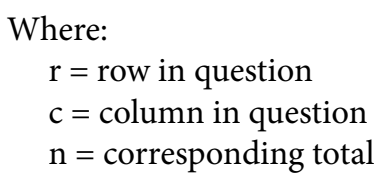

\section{Results and Discussion}

This section presents the discussion of the organoleptic evaluation of blended Taro and Sweet Potato polvoron regarding palatability, texture, flavor, moldability, and overall acceptability.

\section{Acceptability}

Table 3 shows that the overall acceptability treatment and treatment three (3) both obtained equal and highest frequency which "moderately accepted" the mixture of polvoron, and followed by treatment 2 with the same frequency of preference of "very much accepted" and "moderately accepted" the combination. The findings corroborate with the conclusions of Elisabeth (2015) that in Bali, Indonesia, taro and sweet potato flour can be feasible as snack products such as stick bread and chips ${ }^{(9)}$. In accordance with the current findings of Abera, Milkessa \& Gebremedhin, panelists favor the color of the panelists for the sensory properties of the wheat flour taro-based bread to that of the whole wheat bread. It was confirmed that the aroma and taste of bread made with $100 \%$ wheat flour are comparable to bread made with $10 \%$ fermented and $20 \%$ non-fermented cassava flour replacement amounts. However, the air cell was strong in 50\% and 40\% taro, respectively. The best moth feel was found in $10 \%$ taro, followed by $20 \%$ and $30 \%$ taro. This has shown that the taro plant can be exploited entirely and common in countries such as Ethiopia, where food security is a significant issue ${ }^{[10]}$. The rice-sweet potato-based composite flour could serve as a suitable alternative to wheat flour in the production of biscuits. In a newly developed product like biscuit, consumer acceptance is essential. Therefore, the result showed a product with high acceptability ${ }^{(10)}$. According to Nigusse \& Hadero, to some extent, cookies made from wheat, soybean, and sweet potato flour mixes had better proximate composition than wheat cookies. As a result, their utilization would go a long way toward decreasing reliance on wheat imports for wheat flour preparations. Cookies made with sweet potato and soybean flour blended with wheat flour have the same physical and organoleptic properties as cookies made entirely with wheat flour ${ }^{(11)}$.

Table 3. Blended Taro and Sweet Potato Polvoron as to Over-all Acceptability

\begin{tabular}{llll}
\hline Over-All Acceptability & $\mathrm{T}_{1}$ (control) & $\mathrm{T}_{2}$ & $\mathrm{~T}_{3}$ \\
\hline Extremely Accepted & 1 & 3 & 0 \\
Very Much Accepted & 9 & 10 & 6 \\
Moderately Accepted & 14 & 10 & 14 \\
Slightly Accepted & 3 & 6 & 6 \\
Not Accepted & 3 & 1 & 4 \\
\hline
\end{tabular}

\section{Significance}

The Chi-square $\left(\mathrm{x}^{2}\right)$ statistic reveals no significant differences among the treatments regarding palatability preference since the computed F-value of 8.22 is lower than the F critical value of 15.5 at a 0.05 level of significance. This indicates that the amount of taro and sweet potato flour in all the treatments does not significantly differ in taste and preference. The statistic reveals that all the treatments significantly differ regarding texture preference since the computed F-value of 24.4 is greater than the critical value of 15.51 at a 0.5 level of significance. This may be attributed to the pulverized sun-dried taro and sweet potato consistency and the granulated sugar.

The Chi-square (x2) statistic indicates that the treatments are not substantially different in flavor preference since the computed F-value of 14.3 is less than the crucial value of 15.51 at a 0.5 level of significance. This suggests that the inherent flavor of the raw materials does not affect the panelists' flavor preferences. The statistic indicates that all treatments are substantially different from one another in terms of moldability choice, as the computed F-value of 21.6 is larger than the crucial value of 15.51 at a 0.5 level of significance.

The statistic indicates that the treatments are not substantially different in terms of the overall acceptability of the three (3) mixtures since the computed F-value of 8.332 is less than the crucial value of 15.51 at a 0.5 level of significance. This indicates that all the treatments don't differ as to overall acceptability by the panelists. In the study, Sameen et al. (2016), it 
was also evident that there is no significant difference in sensory characteristics values of samples containing sweet potato and taro starch at different concentrations ${ }^{(12)}$. Furthermore, starches from these two sources were compared as granulating agents and disintegrants against commercially available cornstarch. Their functions were not substantially different, indicating that they can be utilized as an alternative starch based on the findings ${ }^{(13)}$. Taro (Colocasia esculenta (L.) Schott, Betelnut) tuber and sweet potato (Ipomoea batatas (L.) Lam) root have proven the molecular weights of proteins with antioxidant and ACE inhibitory action following pepsin digestion. This appears to be advantageous to the health of consumers who consume these meals regularly ${ }^{(14)}$.

\section{Conclusion}

Based on the analysis of the sensory evaluation of the polvoron as to palatability, flavor, and overall liking of the three (3) mixtures, the computed F-value of 8.332 is less than the crucial value of 15.51 at a 0.5 level of significance. The texture and moldability in all the treatments showed that they significantly differ from one another. However, Treatment 1 (control) got a better frequency than overall acceptability and preferred mixture for commercialization. However, the study did not include the blended flour's chemical and nutrient value analysis, which is also essential.

Further studies should be done on the acceptability of blended taro and sweet potato polvoron as influenced by the indigenous preparation of the root crops flour in shelf life and packaging. More Product development studies should be done utilizing the two root crops as raw material for they are locally accessible. To enhance the polvoron, further research should be done.

\section{References}

1) Global Issues: Food Security. (n.d.). Peace Corps. 2021. Available from: https://www.peacecorps.gov/educators/resources/global-issues-food-security/.

2) Saranraj P, Behera SS, Ray RC. Traditional Foods From Tropical Root and Tuber Crops. Innovations in Traditional Foods. 2019;p. 159-191. doi:10.1016/b978-0-12-814887-7.00007-11r.

3) Magbalot-Fernandez A, Umar M. A Review on Root Crops Processing for Food Security and Health. Journal of South Pacific Agriculture. 2018;21(1):26-33.

4) Chandrasekara A. Roots and Tubers as Functional Foods. Reference Series in Phytochemistry. 2018;p. 1-29. Available from: https://doi.org/10.1007/9783-319-54528-8_37-1.

5) Nanbol KK, Namo OAT. The Contribution of Root and Tuber Crops to Food Security: A Review. Journal of Agricultural Science and Technology B. 2019;9(4):221-233. Available from: https://dx.doi.org/10.17265/2161-6264/2019.04.001.

6) Hoppu U, Puputti S, Sandell M. Factors related to sensory properties and consumer acceptance of vegetables. Critical Reviews in Food Science and Nutrition. 2021;61(10):1751-1761. Available from: https://dx.doi.org/10.1080/10408398.2020.1767034.

7) Fiorentini M, Kinchla AJ, Nolden AA. Role of Sensory Evaluation in Consumer Acceptance of Plant-Based Meat Analogs and Meat Extenders: A Scoping Review. Foods. 2020;9(9):1334. Available from: https://dx.doi.org/10.3390/foods9091334.

8) Knorr D, Augustin MA, Tiwari B. Advancing the Role of Food Processing for Improved Integration in Sustainable Food Chains. Frontiers in Nutrition. 2020;7. Available from: https://dx.doi.org/10.3389/fnut.2020.00034.

9) Elisabeth DAA. Added Value Improvement of Taro and Sweet Potato Commodities by Doing Snack Processing Activity. Procedia Food Science. 2015;3:262273. Available from: https://dx.doi.org/10.1016/j.profoo.2015.01.029.

10) Awolu OO, Ifesan BOT, Sodipo MA, Ojewunmi ME, Arowosafe CF, Oladeji OA. Optimization of Nutritional and Pasting Properties of Rice-Sweet Potato Based Composite Flour for Biscuit Production. Applied Tropical Agriculture. 2017;22(2):143-149. Available from: https://core.ac.uk/reader/158573535.

11) Nigusse TH, Hadero T. Substitution of Sweet Potato (Ipomoea Batatas) and Soybean (Glycine Max.) Flour with Durum Wheat (Triticum Durum) Flour Effect on Physicochemical and Sensory Characteristics of Cookies. . Available from: https://core.ac.uk/download/pdf/234684848.pdf.

12) Sameen A, Khan MI, Sattar MU, Javid A, Ayub A. Quality evaluation of yoghurt stabilized with sweet potato (Ipomoea batatas) and taro (Colocassia esculenta) starch. International Journal of Food and Allied Sciences. 2016;2(1):23-23. Available from: https://dx.doi.org/10.21620/ijfaas.2016123-29.

13) Subhadhirasakul S, Yuenyoungsawad S, Ketjinda W, Phadoongsombut N, Faroongsarng D. Study on Tablet Binding and Disintegrating Properties of Alternative Starches Prepared from Taro and Sweet Potato Tubers. Drug Development and Industrial Pharmacy. 2001;27(1):81-87. Available from: https://dx.doi.org/10.1081/ddc- 100000131.

14) Wu CY, Lin KW. The Antioxidative Characteristics of Taro and Sweet Potato Protein Hydrolysates and Their Inhibitory Capability on Angiotensin Converting Enzyme. Food Science and Technology Research. 2017;23(6):845-853. Available from: https://dx.doi.org/10.3136/fstr.23.845. 